intrauterine pregnancies but has little or no effect on the incidence of ectopic pregnancies, and therefore the total number of such pregnancies observed is roughly equal to what would be expected if no contraception had been used.

In the past three years we have treated 715 cases with the Yuzpe regimen and had 17 failures, including the present case of an ectopic pregnancy. This rate is compatible with the calculated risk of $10 \%$ for ectopic pregnancies. ${ }^{4}$

We believe that this is the first reported case of an ectopic pregnancy after the Yuzpe regimen. We suggest that patients requesting postcoital treatment should be counselled about this rare but serious complication and warned of the need for prompt examination if they develop severe pelvic pain. Until more evidence is available about the presence or absence of a causative relation between postcoital hormonal treatment and ectopic pregnancies, the history of previous tubal pregnancy would be a strong contraindication to postcoital treatment. A careful vaginal examination at the follow up visit is important, as vaginal bleeding associated with an ectopic pregnancy can be so easily mistaken for a period, as in our patient.

${ }^{1}$ Yuzpe A, Percival Smith R, Rademaker AW. A multicentre clinical investigation employing ethinyloestradiol combined with dL-norgestrel as a post-coital contraceptive agent. Fertil Steril 1982;37:508-13.

${ }^{2}$ Sparrow MJ. Oestrogen interception: the morning-after pill. $N Z$ Med $\mathcal{F}$ $1974 ; 79: 862-4$.

${ }^{3}$ Smythe AR, Underwood PB. Ectopic pregnancy after post-coital diethylstilbestrol. Am f Obstet Gynecol 1975;121:284-5.

${ }^{4}$ Morris JM, Van Wagenen G. Interception: the use of post-ovulatory estrogens to prevent implantation. Am f Obstet Gynecol 1973;115: 101-6.

${ }^{5}$ Yuzpe AA. Post-coital contraception-new considerations in oral contraception. Proceedings of an international symposium, Catholic UniversityLeuven, Leuven, Belgium, Sept 24-25 1981. Biomedical Information Corporation Publications, 1982.

(Accepted 1 fuly 1983)

Margaret Pyke Centre, Soho Square, London W1

ALI A KUBBA, MB, MRCOG, deputy director

JOHN GUILLEBAUD, FRCSED, MRCOG, medical director

Correspondence to: Dr Ali A Kubba.

\section{Superior sagittal sinus thrombosis and essential thrombocythaemia}

Both bleeding and thrombosis are complications of essential thrombocythaemia. ${ }^{1}$ Common sites of thrombosis are the splenic vein ${ }^{1}$ and the small vessels of the foot, ${ }^{2}$ and the sagittal sinuses are rarely affected. Neurological symptoms such as amaurosis fugax, recurrent vertigo, and recurrent hemiparesis may occasionally be associated with thrombosis due to essential thrombocythaemia. ${ }^{34}$ We describe two patients with essential thrombocythaemia who presented with persistent headaches and chronic papilloedema. One patient was shown to have thrombosis of the superior sagittal sinus, and the second probably had a similar cerebral venous thrombosis.

\section{Case reports}

CASE 1

A 28 year old woman teacher presented to this hospital in 1980 complaining of severe headaches during the past six months made worse by coughing and bending. She had had two miscarriages, one in April 1979 at 16 weeks' gestation and the other in April 1980 at 24 weeks' gestation. She had stopped taking the contraceptive pill in April 1978.

On examination she was alert but had severe bilateral papilloedema. Visual acuity was $6 / 6$ bilaterally and the visual fields were normal. There were no other abnormal findings. A gammascan and computed tomography of the head yielded normal results. Lumbar puncture showed a cerebrospinal fluid pressure of $3 \cdot 15 \mathrm{cmH}_{2} \mathrm{O}$, but further examination of the cerebrospinal fluid gave normal results. Left carotid arteriography showed superior sagittal sinus thrombosis with occlusion of the sinus at the vertex. Haemoglobin concentration was $13.9 \mathrm{~g} / \mathrm{dl}$ and white cell count was $9.1 \times 10^{9} / 1$ with a normal differential, but the platelet count was $748 \times 10^{9} / 1$ and subsequently varied between this level and $934 \times 10^{9} / 1$. The erythrocyte sedimentation rate was $15 \mathrm{~mm}$ in the first hour. Total cellularity of the bone marrow was normal but there were increased numbers of megakaryocytes. There was no cause for secondary thrombocytosis, and essential thrombo- cythaemia was diagnosed. Platelet aggregation in response to adenosine diphosphate, adrenaline, and collagen was normal. She underwent bilatera decompression of the optic nerve in October 1980 and was treated with hydroxyurea. The platelet count fell to within the normal range and her symptoms resolved, but mild papilloedema persisted.

\section{CASE 2}

In 1977 a 38 year old Iranian woman presented with visual obscurations. Examination showed bilateral papilloedema but no other abnormal physical signs. She had never taken the contraceptive pill. Cerebrospinal fluid tests, a gammascan, and serial computed tomography of the head over three years gave normal results. Benign intracranial hypertension was diagnosed. She was found to have thrombocytosis and was referred to this hospital. Her platelet count was $1326 \times 10^{9} / 1$. Haemoglobin concentration was $13.1 \mathrm{~g} / \mathrm{dl}$ and white cell count $9.5 \times 10^{9} / 1(6 \%$ myelocytes, $1 \%$ metamyelocytes, $50 \%$ neutrophils, $35 \%$ lymphocytes, $3 \%$ eosinophils, $5 \%$ monocytes). Total cellularity of the bone marrow was normal, but increased numbers of megakaryocytes were present. Essential thrombocythaemia was diagnosed. Platelet aggregation in response to adenosine diphosphate, adrenaline, and collagen was normal. She was treated initially with pipobroman and subsequently with one dose of radioactive phosphorus. The thrombocytosis and her symptoms resolved. Mild papilloedema persisted for six years but otherwise she remained well.

\section{Comment}

Spontaneous thrombosis of the superior sagittal sinus is rare $^{5}$ and may present as isolated papilloedema. The classic predisposing factors such as sepsis, malignancy, polycythaemia rubra vera, pregnancy, and the puerperium are often absent. This condition was demonstrated in one patient in this report and was strongly suspected in the other; both patients had essential thrombocythaemia. Anticoagulants were not used in either case because of the associated thrombocytosis.

${ }^{1}$ Gunz FW. Haemorrhagic thrombocythaemia: a critical review. Blood $1960 ; 15: 706-23$

2 Preston FE, Emmanuel IG, Winfield DA, Malia RG. Essential thrombocythaemia and peripheral gangrene. $B r$ Med $\mathcal{f} 1974$;iii:548-52.

${ }^{3}$ Levine J, Swanson PD. Idiopathic thrombocytosis. Neurology 1968;18 711-3.

4 Preston FE, Martin JF, Stewart RM, Davies-Jones GAB. Thrombocytosis, circulating platelet aggregates, and neurological dysfunction. Br Med f 1979;ii:1561-3.

${ }^{5}$ Humphrey PRD, Clarke CRA, Greenwood RG. Cerebral venous thrombosis. In: Harrison JG, Dyken ML, eds. Cerebral vascular disease. Sevenoaks, Kent: Butterworths, 1983.

(Accepted 12 fuly 1983)

St Bartholomew's Hospital, London EC1A 7BE

M F MURPHY, MRCP, MRCPATH, senior registrar in haematology

C R A CLARKE, MB, MRCP, consultant neurologist

R L BREARLEY, MD, MRCPATH, senior registrar in haematology

Correspondence to: Dr M F Murphy.

\section{Low protein diets in uraemia}

Patients with chronic renal failure usually receive dietary advice as a palliative measure to reduce uraemic symptoms, but some start dialysis without having reduced their protein intake. In both experimental animals and man early protein restriction slows the rate of progression of renal failure. ${ }^{12}$ We reviewed our experience of low protein diets to alleviate uraemic symptoms in patients approaching end stage renal failure referred to this unit for maintenance dialysis.

\section{Patients, methods, and results}

Over the past five years (1977-82) 176 patients were accepted for dialysis 20 continued to be managed conservatively and 68 received no dietary treatment because of late referral. Of the remainder, 12 had evidence of protein malnutrition-that is, low serum albumin concentrations or low ratios of serum urea to creatinine concentrations-and did not receive advice to reduce protein intake. Ninety six patients were placed on diets containing 35-45 g protein (about $0.6 \mathrm{~g} / \mathrm{kg}$ body weight) and $19-23 \mathrm{mmol}$ 
(600-700 mg) phosphorus a day. Dietary advice was reinforced at regular clinic visits, and adherence to the diet was assessed by a combination of dietary checks and measurement of ratios of urea to creatinine concentrations. The rate of progression of renal function before and during the diet was assessed by plotting the reciprocal of serum creatinine concentrations against time. ${ }^{3}$ Paired Student's $t$ test was used for statistical analysis.

Full data were available on 31 patients (age range 17-65 (mean 47)), who were studied for three to 62 (mean 18) months and had a mean (SEM) serum creatinine concentration of $819(45) \mu \mathrm{mol} / 1(9.3(0.5) \mathrm{mg} / 100 \mathrm{ml})$ and a mean serum urea concentration of $37(2) \mathrm{mmol} / \mathrm{l}(222(12) \mathrm{mg} / 100 \mathrm{ml})$ at the start of dietary treatment. Mean serum phosphate concentration remained stable at $2 \cdot 17(0.12) \mathrm{mmol} / 1(6.7(0.4) \mathrm{mg} / 100 \mathrm{ml})$ before the diet and $1.95(0.08) \mathrm{mmol} / 1(6.0(0.2) \mathrm{mg} / 100 \mathrm{ml})$ during the diet.

For the whole group there was a highly significant $(\mathrm{p}<0.001)$ change in the slopes showing progression of disease from - $1 \cdot 17(0 \cdot 17)\left(\times 10^{-4}\right)$ before the diet to $-0.5(0.11)\left(\times 10^{-4}\right)$ during the diet. Twenty seven patients responded to dietary treatment, as shown by a change in the angle of the slope. The figure shows individual progression slopes for those who responded according to the serum creatinine concentrations at the start of the diet and for those who did not respond. There was also a highly significant $(p<0.001)$ change in the mean ratio of urea to creatinine concentrations from 0.049 $(0.002)$ before the diet to $0.041(0.001)$ during the diet. Only one patien with proteinuria ( $>5 \mathrm{~g} / 24 \mathrm{~h}$ ) showed evidence of protein depletion with persistently reduced total serum protein and serum albumin concentrations.
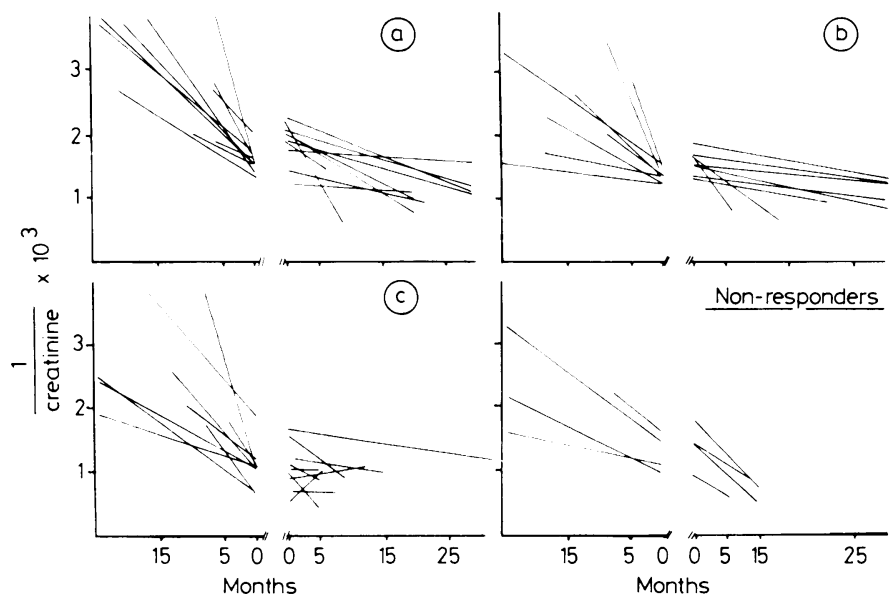

Effect of low protein diet on progression of renal function in patients with chronic renal failure. Patients are grouped according to serum creatinine concentrations at the start of the diet : (a) initial concentration $<650 \mu \mathrm{mol} / \mathrm{l}$ $(7.4 \mathrm{mg} / 100 \mathrm{ml}) ;(b)$ initial concentration $<850 \mu \mathrm{mol} / 1(9.7 \mathrm{mg} / 100 \mathrm{ml})$ (c) initial concentration $=851 \mu \mathrm{mol} / 1(9 \cdot 7 \mathrm{mg} / 100 \mathrm{ml})$

\section{Comment}

This study shows that deterioration in renal function can be slowed significantly by a diet containing $35-45 \mathrm{~g}$ protein, which is double the amount allowed in a previous diet. ${ }^{4}$ The exact mechanism of the effect has not been determined and may depend on several factors including control of blood pressure and serum phosphate concentrations. ${ }^{1}$

There are no recent guidelines on when to restrict protein intake in chronic renal failure, although the onset of uraemic symptoms used to be a criterion. Our data (figure) suggest that dietary modifications should be introduced early-that is, when serum creatinine concentrations are less than $650 \mu \mathrm{mol} / \mathrm{l}(7.4 \mathrm{mg} / 100 \mathrm{ml})$ - to obtain maximum response. Some patients were given a long time (up to several years) free from dialysis. It has never been claimed that a low protein diet should be a substitute for efficient dialysis when that is indicated. Dietary modification early in the course of chronic renal failure, however, can delay the start of dialysis, thereby allowing more efficient use of existing dialysis facilities.

As we had sufficient data for fewer than half the patients treated further controlled studies of the role of dietary protein are required to ascertain the best method of treatment and to avoid protein malnutrition. The study highlights the need for early patient referral to specialist renal units to obtain maximum benefits from dietary modifications.

${ }^{1}$ Brenner BM, Meyer TW, Hostetter TH. Dietary protein intake and the progressive nature of kidney disease. $N$ Englf Med 1982;307:652-9.

${ }^{2}$ Maschio G, Oldrizzi R, Tessitore N, et al. Effects of dietary protein and phosphorus restriction on the progression of early renal failure. Kidney Int 1982;22:371-6.
${ }^{3}$ Mitch WE, Walser M, Buffington GA, Lemann J. A simple method of estimating progression of chronic renal failure. Lancet 1976;ii:1326-8.

4 Giovannetti S, Maggiore Q. A low nitrogen diet with proteins of high biological value for severe chronic uraemia. Lancet 1964 ; :1000-3.

(Accepted 28 June 1983)

Area Renal Unit, Leicester General Hospital, Leicester LE5 4PW $S$ E BENNETT, SRD, renal dietitian

G I RUSSELL, MD, MRCP, senior registrar

J WALLS, MB, FRCP, consultant nephrologist

Correspondence to: $\mathrm{Dr} \mathrm{J}$ Walls.

\section{Paget's disease of bone in Ireland}

Little is known about the occurrence of Paget's disease of bone in Ireland. Recent radiological surveys in 31 British towns and 13 towns in nine other European countries showed wide variations in prevalence. ${ }^{12}$ The highest values were in Britain: only in France did the prevalences reach the lowest values among the British towns.

Although Ireland was not included in the radiological surveys in Europe, information was obtained from responses to a preliminary postal questionnaire sent to a sample of radiologists in every Western European country. The questionnaire inquired about the average frequency with which Paget's disease was seen as either the principal abnormality or, more often, as an incidental one. A map based on the 1416 responses showed a pattern of distribution similar to that obtained in the subsequent radiological surveys.

Replies from four centres in Eire suggested that the frequency in Dublin was somewhat lower than that in Britain and that the frequency in Cork, Limerick, and Galway was much lower. Replies from Belfast (received during a pilot study of the questionnaire) indicated a frequency similar to that in Dublin.

\section{Present study and results}

In order to corroborate the findings in Eire radiological surveys were carried out in Dublin and Galway. The method used was identical with that in previous surveys. ${ }^{2}$ A consecutive sample of abdominal radiographs of people aged 55 and over was taken from films stored in hospitals. The selected films showed the entire pelvis and sacrum, the femoral heads, and all lumbar vertebrae- sites that are affected in $95 \%$ of patients with Paget's disease. The numbers of radiographs for men and women were similar. Standardised criteria were used for diagnosing the disease.

The table gives the results. The prevalence rates in each sex were directly age standardised. As in other surveys the combined population of the 14 British towns initially studied was used as the standard, so that the results of all subsequent surveys were directly comparable. The prevalence

Prevalence of Paget's disease among hospital patients aged 55 years and over

\begin{tabular}{|c|c|c|c|c|c|}
\hline & \multirow{2}{*}{$\begin{array}{c}\text { No of } \\
\text { patients }\end{array}$} & \multirow{2}{*}{$\begin{array}{c}\text { No with } \\
\text { disease }\end{array}$} & \multicolumn{3}{|c|}{ Prevalence $\left(\begin{array}{c}0 \\
0\end{array}\right)$ of Paget's disease } \\
\hline & & & $\begin{array}{c}\text { Men } \\
(\mathrm{n}=884)\end{array}$ & $\begin{array}{l}\text { Women* } \\
(\mathrm{n}=768)\end{array}$ & $\underset{\text { sexes } \dagger}{\text { Both }}$ \\
\hline $\begin{array}{l}\text { Dublin } \\
\text { Galway }\end{array}$ & $\begin{array}{l}938 \\
714\end{array}$ & $\begin{array}{r}15 \\
4\end{array}$ & $\begin{array}{l}1.8 \\
0.6\end{array}$ & $\begin{array}{l}1.6 \\
0.7\end{array}$ & $\begin{array}{l}1.7 \\
0.7\end{array}$ \\
\hline
\end{tabular}

*Age standardised rates.

+Age and sex standardised rates.

of $1.7 \%$ in Dublin was lower than those in any of the 31 British towns surveyed, where the range was $8.3 \%$ to $2.3 \%$. It was also lower than the values recorded in the three French towns surveyed (range $2.7 \%$ to $2.0 \%$ ) The prevalence of $0.7 \%$ in Galway was comparable to values in European towns outside Britain and France (range $1.3 \%$ to $0.4 \%$ ). The numbers of cases in Dublin (15) and Galway (4) were too small to give reliable age specific rates, but there was no evident difference in the age distribution of the disease between Eire and Britain.

\section{Comment}

The low prevalence in Dublin, situated so close to Britain, is remarkable. It is difficult to reconcile with the recent hypothesis that the disease is due to infection with a virus, ${ }^{3}$ since the virus must be 